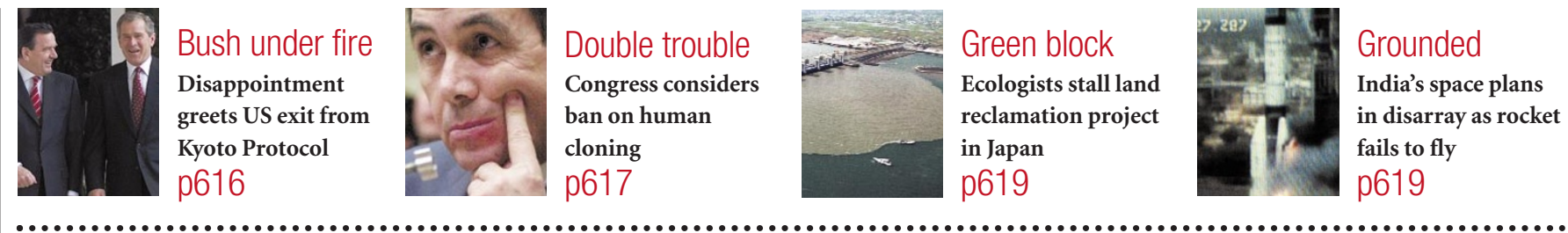

\title{
Experts clash over likely impact of cheap AIDS drugs in Africa
}

Meredith Wadman, Washington

Conflict is brewing between clinicians treating AIDS patients and some public-health experts over the wisdom of distributing cutprice AIDS drugs rapidly in poor countries.

While hard-pressed doctors are trying to get the medicines out as quickly as possible, others warn that they may do more harm than good, diverting scarce funds from more costeffective preventive measures and perhaps raising new problems with drug resistance and side effects.

"We have to ask what capabilities need to be put in place to make sure the problem isn't made worse," says Tom Coates, director of the AIDS Research Institute at the University of California, San Francisco.

"Parachuting drugs into countries and saying, 'Here they are, go for it!' could do a considerable amount of harm in addition to the good we're expecting," says Tony Fauci, director of the National Institute of Allergy and Infectious Diseases.

The warnings follow the decision last

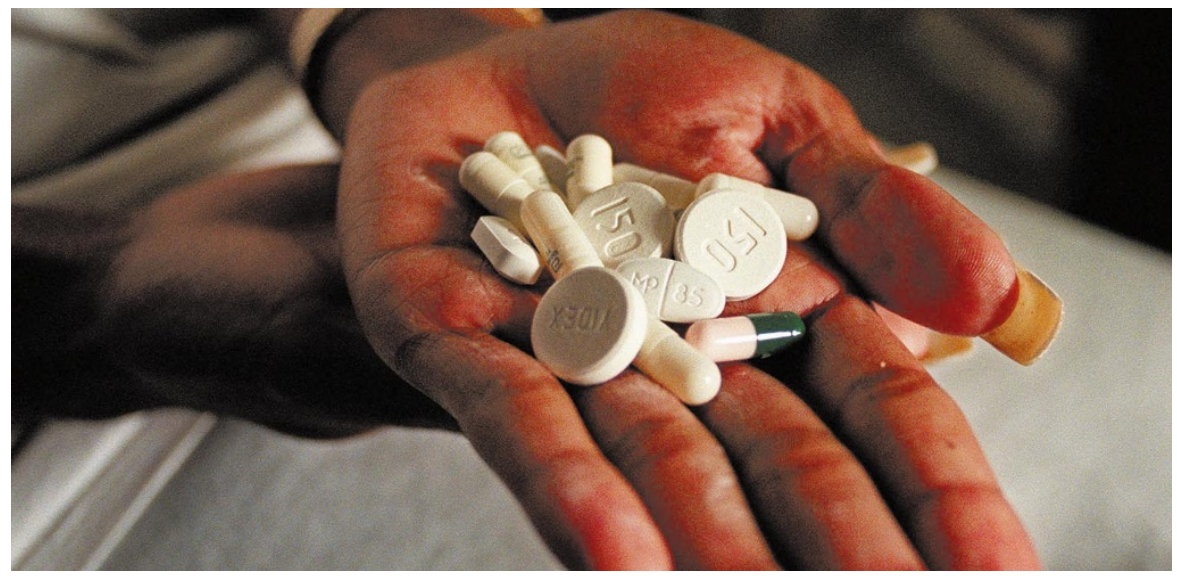

Hard to swallow: combination pills that make AIDS drug regimens easier to follow are on the way.

month by several leading drug companies to slash the prices of AIDS drugs for sub-Saharan Africa, home to $70 \%$ of the world's HIVinfected people (see Nature 410, 289; 2001). The new prices followed moves by genericdrug makers in India and elsewhere to defy

\section{Farmer fined for growing GM seed}

David Spurgeon, Montreal

A Canadian judge has ruled that a farmer must pay royalties to the biotechnology giant Monsanto for growing its genetically modified seed without the supplier's permission.

Percy Schmeiser, a 70-year-old grain farmer from Bruno, Saskatchewan, says the Roundup Ready canola (oilseed rape) seed found growing on his land was the result of contamination by pollen from neighbouring fields or seed blown off passing trucks. Monsanto said he knowingly planted it without paying for it.

But without ruling directly on that question, Justice Andrew MacKay said Schmeiser had infringed Monsanto's licences, and gave both sets of lawyers three weeks to settle appropriate damages. If they fail, he has ruled, Schmeiser must pay Monsanto a licence fee of Can\$15,450 (US\$9,800) — not the Can\$105,000 demanded by the company. Moreover, the judge declined to order additional exemplary damages.

Schmeiser's lawyer, Terry Zakreski, argued that Monsanto had lost its exclusive rights to its patent on the genewhich allows plants to survive the application of Monsanto's weedkiller Roundup - when it was released into the environment. He said farmers are allowed to keep seed from their crops to plant the following year, and although Monsanto requires farmers using its canola seeds to sign an agreement that they will not do so, the company has no such power over farmers who do not buy Roundup Ready canola.

Trish Jordan, a spokeswoman for Monsanto in Canada, said the decision will help to protect the property rights of the company and of the thousands of farmers who pay for its technology.

^๑ 2001 Macmillan Magazines Ltd patents and distribute AIDS drug cocktails in Africa (see Nature 409, 751;2001).

These actions created an unprecedented momentum for the wide distribution of AIDS medicines on a continent where, just a few months ago, no one dreamt of broad access to expensive, life-saving therapies.

But some public-health experts worry that the arrival of more of the drugs will eat into crucial AIDS-prevention budgets. They also say that the infrastructure in many places will not support proper drug distribution, and that bad distribution and monitoring may give rise to strains of the virus that will resist known therapies.

Barry Bloom, dean of the Harvard School of Public Health, says AIDS drugs should be dispensed only under direct observation - a strategy that has worked for tuberculosis and that may not only prevent resistance, but also stop black markets from developing.

These arguments inflame doctors and activists working with AIDS patients in poor countries. The warnings are reminiscent, they say, of the now-debunked criticism of widescale immunization initiatives a generation ago. Anne-Valerie Kaninda, a medical adviser to Doctors Without Borders (Médecins sans Frontières) in New York, says: "The limited experience of introducing antiretrovirals [in poor countries] shows that there are solutions to the problems."

One case study in particular backs up 
their argument. Four years ago the Brazilian government began providing free cocktails of three AIDS drugs. Despite an imperfect public-health system, the country's AIDS death rate has been halved. Last year, the number of new infections was half of that predicted by the World Bank in 1994.

"It's horribly difficult to make [drug distribution] happen. But it is possible," says Ezio Santos Filho, a Brazilian activist whose group, Grupo Pela Vidda, has helped push for the programme. "What we cannot accept is the excuse that the regimens are just too difficult" for Africans "We have to make these medications available by all means possible."

The drug companies are playing down the effect their move will have without major infrastructure improvements. "There's a need for more AIDS specialists to make sure these patients take their medicines properly every day, so that we avoid resistance developing and the medicines are truly effective," says Jeff Trewhitt, a spokesman for the Pharmaceutical Research and Manufacturers of America.

But advocates of access to the drugs point out that, even in the United States adherence to complicated drug regimens is hardly a given: recent studies have shown that only two-thirds of people with AIDS take their medicine as much as $80 \%$ of the time. The number in Brazil is about the same, according to a 1999 government study, providing ammunition for those who say the real enemy of getting medicines to Africa is a lack of political will, rather than practical obstacles.

Proponents of widespread distribution also argue that the complicated drug regimens used in rich nations may not be needed in poorer countries. A pilot programme being launched in South Africa this month by Doctors Without Borders will have patients taking three pills twice a day, rather than the 20 or 30 tablets commonly taken in developed countries.

Follow-up tests will be administered less frequently than in the developed world, unless patients show visible deterioration. Ultimately, simpler and cheaper versions of the tests are expected to be produced. And combination pills that make drug regimens easier to follow are already being produced by some drug companies.

Eric Goemaere, the Doctors Without Borders doctor in charge of the pilot programme in Khaelitsha township near Cape Town, admits that this approach to monitoring has not been scientifically validated. "What we need to develop is a science for low-income countries," he says But he adds that he is not prepared to wait for that science to emerge before starting treatment. "We see [people] die almost on a daily basis. We feel a bit in a hurry."

\section{Criticism mounts as Bush backs out of Kyoto accord}

\section{Mark Schrope}

Leading US climate scientists are disappointed over President George W. Bush's decision to abandon the Kyoto Protocol for reducing greenhouse-gas emissions.

But unlike Bush's political opponents, who vehemently condemned the move, the researchers still hope Bush will act on climate change once he has appointed key officials.

"I think it would be very unfortunate to scrap the Kyoto Protocol at this point," says James McCarthy, a Harvard oceanographer and co-chair of the Intergovernmental Panel on Climate Change's working group on impacts, adaptation and vulnerability.

McCarthy says a key problem is that Bush has yet to fill all of the main scientific advisory positions in his administration. Sherwood Rowland, an atmospheric scientist at the University of California, Irvine, who shared the 1995 chemistry Nobel prize for his work on ozone, agrees. "The absence of any high-level scientific advice is quite noticeable," he says.

Henry Jacoby, an environmental economist at the Massachusetts Institute of Technology, believes the Bush administration will find a coherent approach to climate change. "Kyoto is a set of numbers and conditions they don't like, but it is also a process, and it is not clear they're rejecting the process," he says.

Before meeting with German Chancellor Gerhard Schröder in Washington last week, Bush said that he would not accept any plan that harms the US economy, as he believes the Kyoto treaty does. After the meeting, Schröder said he disagreed with Bush, but that the United States must make its own decision on climate-change policy.

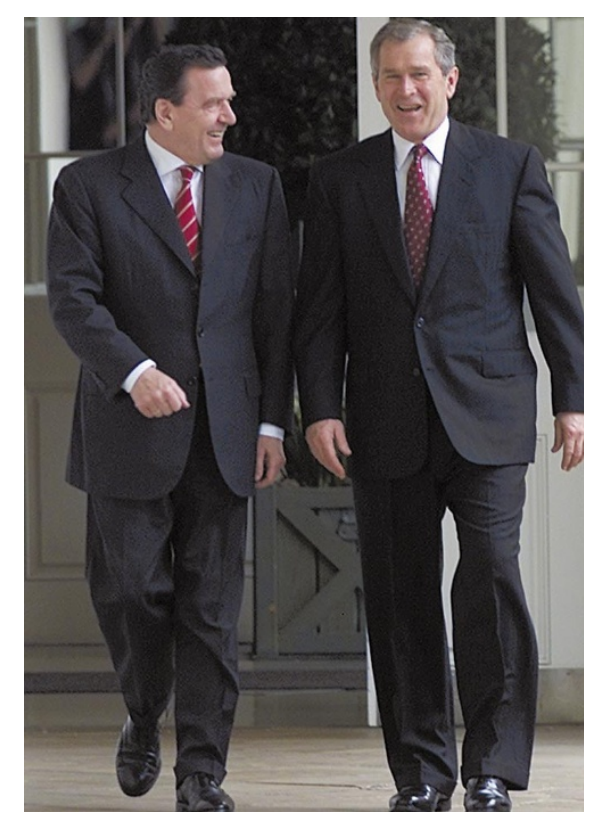

Agreeing to disagree: Bush (right) and Schröder share a joke on their way to last week's meeting.

White House spokesman Ari Fleischer said repeatedly last week that the administration felt no obligation to the treaty because the Senate had rejected it. But the Senate has never voted on the Kyoto Protocol itself.

Senator Joseph Lieberman (Democrat, Connecticut) announced last week that he would investigate the methods used by the Bush administration to make environmental decisions, saying that they "ignore the public interest and defy common sense".

International representatives will meet in Bonn in July to discuss the Kyoto accord.

\section{Climate change transforms island ecosystem}

Peter Pockley, Sydney

The first survey for a decade of animals and plants on Australia's Heard Island, 4,000 kilometres southwest of Perth, has unearthed dramatic evidence of global warming's ecological impact.

The survey found that glaciers

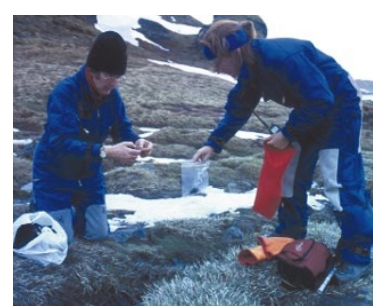

Getting warmer: botanists hunt for clues on Heard Island. on the sub-Antarctic island have retreated by $12 \%$ since the first measurements were taken in 1947. This has been accompanied by a rise in sea surface temperature of up to $1^{\circ} \mathrm{C}$ and rapid increases in flora and fauna.

Dana Bergstrom, an ecologist at the University of Queensland in Brisbane, who led the survey's study of plant life, says areas that were previously poorly vegetated are now "lush with large expanses of plants".

Populations of birds, fur seals and insects have also expanded rapidly since earlier studies, says Eric Woehler of the Australian Antarctic Division at Kingston,
Tasmania, part of Australia's environment department. According to Woehler, the number of king penguins has exploded from only three breeding pairs in 1947 to 25,000 , while the Heard Island cormorant, listed previously as "vulnerable", has increased to 1,200 pairs. From near extinction, fur seals now number 28,000 adults and 1,000 pups.

Australia has now committed to surveying Heard Island every two years for the next decade as part of an international programme to measure the response of ecosystems to climate change in the Antarctic. 